\title{
PENGARUH VCO MENGANDUNG EKSTRAK WORTEL TERHADAP PEROKSIDASI LIPID PLASMA
}

\author{
Lidya Irma Momuat $^{1)}$, Meiske S. Sangi ${ }^{1)}$, Ni Putu Purwati ${ }^{2)}$ \\ ${ }^{1)}$ Program Studi Kimia FMIPA Universitas Sam Ratulangi, Manado 95115 \\ ${ }^{2)}$ Alumni Program Studi Kimia FMIPA Universitas Sam Ratulangi, Manado 95115
}

\begin{abstract}
ABSTRAK
Penelitian ini bertujuan untuk mengukur tingkat oksidasi lipid dalam plasma darah tikus yang diberi pakan VCO mengandung ekstrak wortel. Tikus Wistar jantan pada penelitian ini dibagi menjadi empat kelompok, yaitu (I) pakan standar (kontrol), (II) 10\% VCO tanpa ekstrak wortel, (III) 10\% VCO mengandung ekstrak wortel dan (IV) $10 \%$ minyak jagung. Setelah 4 minggu masa perlakuan, plasma darah dipisahkan dengan sentrifugasi untuk analisis tingkat oksidasi plasma dengan mengukur konsentrasi malondialdehida (MDA) menggunakan metode uji asam tiobarbiturat. Hasil penelitian menunjukkan bahwa konsentrasi MDA tertinggi terdapat pada kelompok tikus yang diberi minyak jagung $(11,253 \mu \mathrm{M})$, diikuti kelompok kontrol $(10,167 \mu \mathrm{M})$, lalu kelompok tikus yang diberi VCO mengandung ekstrak wortel $(8,656 \mu \mathrm{M})$ dan VCO $(8,269 \mu \mathrm{M})$. Penelitian ini menyimpulkan bahwa tingkat oksidasi lipid plasma tikus yang diberi VCO mengandung ekstrak wortel relatif sama dengan yang diberi VCO tanpa ekstrak wortel, tetapi lebih rendah daripada kontrol dan yang diberi minyak jagung.
\end{abstract}

Kata kunci: malondialdehida, minyak kelapa, wortel

\section{EFFECT OF VIRGIN COCONUT OIL (VCO) CONTAINING CARROT EXTRACT ON PLASMA LIPID PEROXIDATION}

\begin{abstract}
The aim of this study was measure the level of lipid oxidation in the blood plasma of rats fed VCO containing carrot extracts. Male Wistar rats in this study were divided into four groups: (i) control, (II) $10 \%$ VCO without the carrot extract, (III) 10\% VCO containing carrot extracts, and (IV) $10 \%$ corn oil. After 4 weeks of treatment, blood from each rat was taken by syringe. Plasma is separated from whole blood by centrifugation for analysis of plasma oxidation levels by measuring the malondialdehyde (MDA) concentration using tiobarbituric acid test. The results showed that the highest concentration of MDA was found in rats fed corn oil $(11.253 \mu \mathrm{M})$, followed by the control group $(10.167 \mu \mathrm{M})$, then rats fed VCO containing carrot extract $(8.656 \mu$ $\mathrm{M})$ and $\mathrm{VCO}(8.269 \mu \mathrm{M})$. This study concluded that the level of plasma lipid oxidation in rats fed VCO containing carrot extracts is relatively similar to rats fed VCO without the carrot extract, but it is lower than the control and corn oil groups.
\end{abstract}

Keywords: malondialdehyde, coconut oil, carrot

\section{PENDAHULUAN}

Dewasa ini diyakini bahwa timbulnya beberapa penyakit seperti kanker, kardiovaskuler, penuaan dini dan beberapa penyakit degeneratif lainnya dapat disebabkan oleh spesies oksigen reaktif yang aktif mengoksidasi komponen dalam tubuh. Untuk mencegah menderita penyakit tersebut, berbagai upaya dapat dilakukan, di antaranya dengan meningkatkan konsumsi antioksidan alami. Sumber antioksidan alami dapat diperoleh dari bahan pangan, seperti buah dan sayuran.

Wortel (Daucus carota L) merupakan salah satu jenis sayuran yang telah dikenal luas oleh masyarakat. Wortel kaya akan kandungan antioksidan, teristimewa $\beta$-karoten yang dapat larut dalam lemak/minyak (Sudjaswadi \& 
Sitangang, 2002). Kemampun $\beta$-karoten sebagai antioksidan terutama didasarkan pada sifatnya sebagai pemunah oksigen singlet. Aktivitas pemunah oksigen singlet dari karotenoid teristimewa bergantung kepada jumlah ikatan rangkap terkonjugasi dari molekul tersebut dan kurang dipengaruhi oleh gugus ujung karotenoid (siklik atau asiklik) atau subtituen yang terikat pada gugus siklik ujung karotenoid (Rao dalam Momuat, 2005).

Penelitian terhadap efek antioksidan dari $\beta$-karoten telah banyak dilakukan. Informasi mengenai efek antioksidan $\beta$ karoten yang dilaporkan umumnya berimplikasi terhadap kesehatan, seperti meningkatkan respon imun dan inhibisi mutagenesis, proteksi terhadap kerusakan sel dan jaringan yang dapat menyebabkan penyakit fotosensitivitas dan kardiovaskuler (Mayne, 1996; Sesso et al., 2004). Karena besarnya manfaat provitamin A ini bagi kesehatan tubuh, sehingga usaha-usaha untuk meningkatkan konsentrasi $\beta$-karoten dalam plasma darah banyak dilakukan, misalnya dengan mengkonsumsi suplemen minyak yang secara alamiah kaya akan kandungan $\beta$ karoten (Lietz et al., 2001) ataupun melakukan fortifikasi minyak kedelai dengan $\beta$-karoten yang ditambahkan ke nasi (Dutrade-Oliveira et al., 1998).

Wortel juga telah dimanfaatkan dalam pembuatan minyak kelapa murni (virgin coconut oil, VCO) (Momuat, 2010). Pada pembuatan minyak tersebut senyawa antioksidan, teristimewa $\beta$ karoten yang terdapat dalam wortel dapat larut dalam minyak sehingga melindungi minyak dari kerusakan yang disebabkan oleh reaksi oksidasi. Sejauh ini belum ada informasi mengenai pengaruh mengkonsumsi VCO yang mengandung ekstrak wortel, terhadap tingkat oksidasi lipid plasma darah. Untuk itu penelitian ini dilakukan dengan tujuan mengukur konsentrasi malondialdehida (MDA) dalam plasma darah tikus yang diberi pakan VCO mengandung ekstrak wortel. Malondialdehida merupakan salah satu senyawa produk oksidasi lipid dalam tubuh dan sering digunakan sebagai indikator terjadinya proses oksidasi lipid. Penelitian ini diharapkan dapat berimplikasi terhadap peningkatan kualitas minyak kelapa serta dapat memberikan informasi tentang tingkat oksidasi lipid (konsentrasi MDA) dalam plasma darah hewan coba yang diberi pakan VCO mengandung ekstrak wortel, terutama dalam upaya pencegahan penyakit yang berhubungan dengan oksidasi lipid seperti PJK.

\section{METODOLOGI PENELITIAN}

\section{Bahan dan Alat}

Bahan yang digunakan dalam penelitian ini adalah plasma darah dari setiap tikus percobaan, VCO tanpa ekstrak wortel, VCO mengandung ekstrak wortel, minyak jagung, campuran mineral dalam ransum $\left(\mathrm{NaCl}, \quad \mathrm{Kl}, \quad \mathrm{KH}_{2} \mathrm{PO}_{4}, \mathrm{MgSO}_{4}\right.$ anhidrida, $\quad \mathrm{CaCO}_{3}, \quad \mathrm{FeSO}_{4} \cdot \mathrm{H}_{2} \mathrm{O}$, $\mathrm{MnSO}_{4} \cdot \mathrm{H}_{2} \mathrm{O}, \quad \mathrm{ZnSO}_{4} \cdot 7 \mathrm{H}_{2} \mathrm{O}, \quad \mathrm{CuSO}_{4} .5 \mathrm{H}_{2}$, $\mathrm{CoCl}_{2} \cdot 6 \mathrm{H}_{2} \mathrm{O}$ ), campuran vitamin (ultravita), protein (susu Protifar), pati jagung (tepung maizena), selulosa (carboxy metyl celulosa, CMC) dan untuk analisa MDA digunakan 1,1,3,3tetrametoksipropana (TMP), trikloroasetat (TCA), asam tiobarbiturat (TBA), aquades, dan asam asetat glasial.

Alat yang digunakan dalam penelitian ini adalah untuk pemeliharaan tikus digunakan kandang, sekam, kamera dan timbangan. Untuk pembuatan VCO mengandung ekstrak wortel digunakan blender, saringan, botol-botol pemisah minyak, pemanas air, gelas ukur, loyang, parutan, dan gilingan kelapa. Untuk analisis MDA digunakan labu takar, neraca analitik, pipet mikro, oven, tabung sentrifugasi, spektrofotometer dan untuk pengambilan darah tikus digunakan disposable syringe, pisau bedah dan tabung sentrifugasi.

\section{Rancangan Penelitian dan Hewan Coba}

Penelitian ini menggunakan 12 ekor tikus jantan strain Wistar yang berumur 2 bulan dengan berat badan relatif sama. Setiap ekor tikus ditempatkan dalam satu kandang. Sebelum dilakukan analisis MDA, tikus diadaptasikan terlebih dahulu pada keadaan laboratorium selama 7 hari dengan pemberian pakan standar yang mengandung $8 \% \mathrm{~b} / \mathrm{b}$ minyak jagung, sesuai komposisi pakan untuk penentuan 
protein efficiency ratio menurut AOAC (1990) (Tabel 1).

Tabel 1. Komposisi Pakan Standar Tikus.

\begin{tabular}{|l|c|}
\hline \multicolumn{1}{|c|}{ Bahan-bahan Campuran } & $\begin{array}{c}\text { Jumlah } \\
(\%)\end{array}$ \\
\hline \hline Protein & 10 \\
Minyak & 8 \\
Campuran garam mineral & 5 \\
Campuran vitamin & 1 \\
Selulosa & 1 \\
Air & 5 \\
Pati jagung untuk membuat $100 \%$ & \\
\hline
\end{tabular}

Sumber: AOAC, 1990.

Pada hari ke-8, dengan menggunakan metode penarikan contoh acak, tikus tersebut dibagi menjadi empat kelompok pakan, yaitu kelompok I: pakan standar (kontrol), II: pakan standar ditambah $10 \%$ VCO tanpa ekstrak wortel, III: pakan standar ditambah 10\% VCO mengandung ekstrak wortel dan IV: pakan standar ditambah $10 \%$ minyak jagung (Tabel 2). Setiap kelompok terdiri atas 3 ekor tikus. Tikus-tikus tersebut diperoleh dari POLTEKES Farmasi Manado. Pemberian pakan dilakukan setiap pagi, dan air minum diberi secara ad libitum (terus menerus). Perlakuan diberikan selama 4 minggu.

Tabel 2. Susunan Pakan dalam Setiap 1000 gram Pakan Standar

\begin{tabular}{|l|l|l|l|l|}
\hline \multirow{2}{*}{ Nama Bahan } & \multicolumn{4}{|l|}{ Kelompok } \\
\cline { 2 - 5 } & $\mathrm{I}(\mathrm{g})$ & $\mathrm{II}(\mathrm{g})$ & $\mathrm{III}(\mathrm{g})$ & $\mathrm{IV}(\mathrm{g})$ \\
\hline Kasein & 145 & 145 & 145 & 145 \\
Campuran mineral & 50 & 45 & 50 & 50 \\
Campuran vitamin & 10 & 10 & 10 & 10 \\
Minyak jagung & 80 & 80 & 80 & 80 \\
VCO & - & 100 & - & - \\
VCO + tomat & - & - & 100 & - \\
Minyak jagung & - & - & - & 100 \\
CMC & 10 & 10 & 10 & 10 \\
Air & 50 & 50 & 50 & 50 \\
Pati jagung & 655 & 655 & 655 & 655 \\
\hline
\end{tabular}

\section{Pengambilan dan Pemisahan Plasma Darah Tikus}

Sebelum pengambilan darah, tikus dipuasakan selama semalam. Tikus dibius dengan dietil eter, caranya dietil eter dimasukkan ke dalam gelas piala dan ditempatkan di bawah penyangga eksikator. Kemudian tikus dimasukkan dalam eksikator dan ditutup rapat. Selanjutnya darah diambil melalui jantung dengan menggunakan disposable syringe berukuran $2.5 \mathrm{~mL}$. Darah yang telah diambil ditampung dalam tabung sentrifugasi dan disentrifugasi pada kecepatan $3000 \mathrm{rpm}$ selama 10 menit. Selanjutnya, plasma darah yang terletak pada bagian atas dipisahkan dan diambil untuk dianalisis konsentrasi MDA-nya.

\section{Analisis Konsentrasi MDA Plasma}

\section{Pembuatan Kurva Standar}

Larutan stok pereaksi 1,1,3,3tetrametoksipropana (TMP) konsentrasi $6 \mathrm{M}$ diencerkan menjadi $0.5,0.8,1,2,3,4$, $5,6,7,8,9,10,11,12,13,14,15 \mu \mathrm{M}$. Selanjutnya, setiap konsentrasi TMP direaksikan dengan $1.0 \mathrm{~mL}$ TCA $20 \%$ dan $1.0 \mathrm{~mL}$ TBA $1 \%$ dalam pelarut asam asetat glasial $50 \%$. Semua larutan kemudian diinkubasi selama 45 menit pada suhu $95^{\circ} \mathrm{C}$. Setelah didinginkan, larutan disentrifugasi pada kecepatan $1000 \mathrm{rpm}$ selama 15 menit. Supernatan pada lapisan atas diukur absorbansinya dengan menggunakan spektrofotometer pada panjang gelombang $532 \mathrm{~nm}$.

\section{Pengukuran Sampel}

Pengukuran konsentrasi dari sampel percobaan dilakukan dengan cara yang sama seperti larutan standar, yaitu 
1.0 mL plasma darah direaksikan dengan $1.0 \mathrm{~mL}$ TCA $20 \%$ dan $1.0 \mathrm{~mL}$ TBA $1 \%$ dalam asam asetat glasial $50 \%$, kemudian diinkubasi selama 45 menit pada suhu $95^{\circ} \mathrm{C}$, lalu dibiarkan dingin. Larutan disentrifugasi selama 15 menit pada kecepatan 1000 rpm. Supernatan dipisahkan kemudian diukur absorbansinya menggunakan spektrofotometer pada panjang gelombang $532 \mathrm{~nm}$. Konsentrasi sampel diperoleh dengan memplot data absorbansi sampel ke dalam kurva standar.

\section{HASIL DAN PEMBAHASAN}

Hasil pengukuran konsentrasi malondialdehida (MDA) plasma dari ke-4 kelompok perlakuan pakan tertera pada Tabel 3. Hasil yang diperoleh menunjukkan bahwa konsentrasi MDA tertinggi terdapat pada kelompok tikus yang diberi pakan stadar ditambah 10\% minyak jagung (kelompok IV), diikuti kelompok kontrol (kelompok I), lalu kelompok tikus yang diberi pakan stadar ditambah 10\% VCO mengandung ekstrak wortel (kelompok III), dan yang terendah pada kelompok tikus yang diberi pakan stadar ditambah 10\% VCO (kelompok II). Hasil analisis statistika memperlihatkan adanya perbedaan konsentrasi MDA yang signifikan antara kelompok kontrol (I) dengan kelompok II, III, dan IV. Namun, konsentrasi MDA antara kelompok II dan III tidak berbeda secara signifikan.

Tabel 3. Konsentrasi MDA plasma pada setiap perlakuan

\begin{tabular}{|l|c|}
\hline \multicolumn{1}{|c|}{ Kelompok } & $\begin{array}{c}\text { Konsentrasi MDA } \\
(\mu \mathrm{M})\end{array}$ \\
\hline I: Pakan standar (PS) & $10,167 \pm 1,006 \mathrm{a}$ \\
\hline II: PS + 10\% VCO & $8,269 \pm 0,057 \mathrm{~b}$ \\
\hline $\begin{array}{l}\text { III: PS + 10\% } \\
\text { VCO_wortel }\end{array}$ & $8,656 \pm 0,145 \mathrm{~b}$ \\
\hline IV: PS + minyak jagung & $11,253 \pm 0,113 \mathrm{c}$ \\
\hline
\end{tabular}

Ket.: huruf berbeda dibelakang konsentrasi MDA menunjukkan perbedaan signifikan $(\alpha=5 \%)$

Rendahnya konsentrasi MDA plasma pada tikus yang diberi VCO mengandung ekstrak wortel disebabkan oleh adanya senyawa karotenoid, teristimewa $\beta$-karoten, dalam minyak tersebut. Terlarutnya $\beta$ karoten dalam VCO ditandai oleh warna jingga dari minyak tersebut. Momuat (2010) mengemukakan bahwa $\beta$-karoten merupakan pigmen warna jingga yang terdapat dalam wortel dan bersifat larut dalam lipid, serta memiliki peran sebagai antioksidan. Kemampuan karotenoid sebagai antioksidan terletak pada struktur kimia $\beta$-karoten yang mengandung sejumlah diena terkonjugasi yang berperan sebagai kuenser atau pemunah oksigen singlet penyebab reaksi oksidasi (Huang et al., 2005).

Konsentrasi MDA pada kelompok II yang diberi pakan dengan penambahan $10 \%$ VCO juga lebih besar daripada kelompok kontrol (Tabel 2). Hasil ini menunjukkan bahwa mengkonsumsi VCO dapat menurunkan tingkat oksidasi dalam plasma. Hasil penelitian ini mendukung penelitian yang dilakukan oleh Nevin dan Rajamohan (2006) yang melaporkan bahwa pada tikus jantan Sprague-Dawley yang diberikan VCO selama 45 hari memiliki status antioksidan yang lebih tinggi dan konsentrasi MDA dalam jaringan yang lebih rendah daripada tikus yang diberi minyak kacang tanah dan minyak kopra. Marina et al. (2009) mengemukakan bahwa VCO mengandung senyawa fenolik, seperti asam ferulat and $p$ coumarat yang memberikan kontribusi terhadap aktivitas antioksidan VCO.

Konsentrasi MDA plasma pada kelompok II yang diberi VCO relatif sama dengan kelompok III yang diberi VCO mengandung ekstrak wortel (Tabel 2). Konsentrasi MDA yang relatif sama pada ke2 kelompok tersebut menunjukkan bahwa ekstrak wortel, teristimewa $\beta$-karoten yang dikonsumsi oleh tikus pada kelompok III, belum menunjukkan kemampuan antioksidannya dibandingkan dengan VCO yang dikonsumsi oleh kelompok II. Belum tampaknya efek antioksidan dari ekstrak wortel dapat disebabkan oleh masih kurangnya ekstrak wortel yang digunakan dalam pembuatan VCO (30\%-v/v). Penelitian mengenai perbandingan efek antioksidan dari berbagai senyawa karotenoid yang dilakukan oleh Heber dan Lu (2000) menunjukkan bahwa pada konsentrasi yang sama, aktivitas antioksidan $\beta$-karoten lebih rendah daripada likopen dan $\alpha$-karoten.

Konsentrasi MDA pada kelompok IV yang diberi pakan dengan penambahan $10 \%$ minyak jagung lebih tinggi daripada kelompok I, II dan III. Tingginya konsentrasi 
MDA kelompok IV menunjukkan bahwa mengkonsumsi minyak jagung yang berlebih selama 4 minggu dapat meningkatkan tingkat oksidasi dalam plasma darah hewan coba. Hal ini sejalan dengan yang dikemukakan oleh Ketaren (1986) bahwa asam lemak takjenuh lebih mudah dioksidasi daripada asam lemak jenuh. Menurutnya, minyak jagung sebagian besar terdiri dari asam lemak takjenuh, yaitu linoleat sebesar $56 \%$ dan oleat sebesar 30\%. Tingginya konsentrasi MDA dalam plasma darah hewan pada kelompok IV kemungkinan disebabkan oleh oksidasi yang terjadi pada asam lemak tak-jenuh tersebut.

Malondialdehida adalah senyawa dialdehida yang mengandung tiga atom karbon dengan gugus karbonil berada pada posisi atom $\mathrm{C}_{1}$ dan $\mathrm{C}_{3}$. MDA mempunyai rumus kimia $\mathrm{C}_{3} \mathrm{H}_{4} \mathrm{O}_{2}$ dengan berat molekul
72. Reaksi pembentukkan MDA diawali dengan terbentuknya radikal lipid akibat serangan radikal bebas pada ikatan takjenuh dari suatu asam lemak. Pengukuran konsentrasi MDA dalam penelitian ini menggunakan metode uji asam tiobarbiturat (tiobarbituric acid, TBA). MDA bila direaksikan dengan TBA dalam suasana asam akan menghasilkan kompleks MDA-TBA yang berwarna merah muda (Gambar 1). Janero (1990) melaporkan bahwa MDA dan metode uji TBA merupakan metode yang paling banyak digunakan sebagai indeks diagnosa kerusakan/terjadinya peroksidasi lipid dan pembentukan hidroperoksida lemak. Reaktivitas MDA-TBA merupakan indikator bagi peroksidasi lipid, baik secara kualitatif maupun kuantitatif.

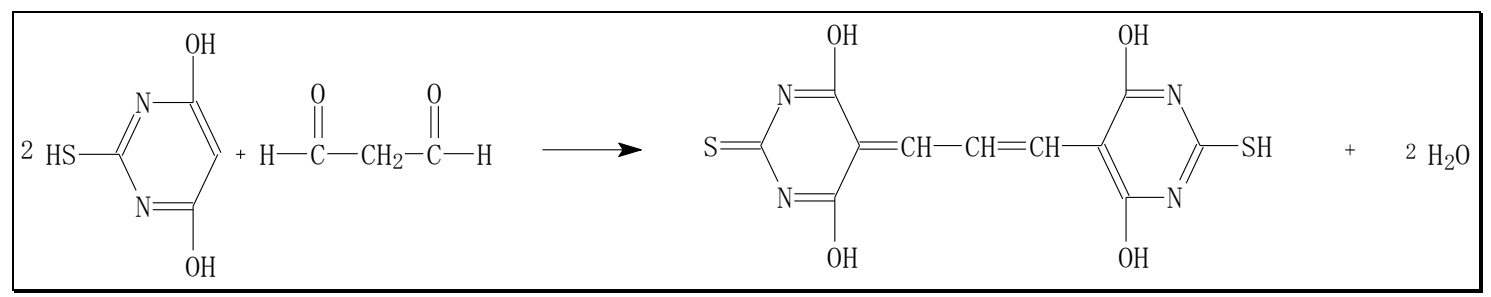

Gambar 1. Reaksi Pembentukan Kompleks TBA-MDA (Nawar dalam Sugiman, 2000)

\section{KESIMPULAN}

Konsentrasi MDA plasma darah tikus yang diberi VCO mengandung ekstrak wortel $(8.656 \mu \mathrm{M})$ relatif sama dengan yang diberi VCO tanpa ekstrak wortel $(8,269 \mu \mathrm{M})$, dan lebih rendah daripada kontrol $(10.167 \mu \mathrm{M})$ dan yang diberi minyak jagung $(11,253 \mu \mathrm{M})$.

\section{DAFTAR PUSTAKA}

AOAC. 1990. Official methods of analysis. AOAC, Inc. Virginia.

Dutra-de-Oliveira, J.F., R.M.D. Fávaro, I.R. Leonardo, A.A. Jordão, H. Vannucchi. 1998. Absorption, by human, of $\beta$ carotene from fortified soybean oil added to rice: effect of heat treatment. J. Am. Coll. Nutr. 17(4):361-365.
Heber, D., Q.Y. Lu. 2002. Overview of Mechanisms of Action of Lycopene. Exp Biol Med 227: 10 920-923.

Huang, D., B. Ou, R.L. Prioi. 2005. The Chemistry behind Antioxidant Capacity Assays. J. Agric. Food Chem. 53:1841-1856.

Janero, D.R. 1990. Malondialdehyde and thiobarbituric acid-reactivity as diagnostic indices of lipid peroxidation and peroxidative tissue injury. Free Radical Biology and Medicine 9(6):515-540.

Ketaren, S. 1986. Pengantar Teknologi Minyak dan Lemak Pangan. UI-Press, Jakarta.

Lietz, D., et al. 2001. Comparison of the effects of supplemental red palm oil and sunflower oil on maternal vitamin A status. Am. J. Clin. Nutr. 74(4):501509. 
Marina, A.M., Y.B. Cheman, S.A.H. Nazimah, I. Amin. 2009. Antioxidant capacity and phenolic acids of virgin coconut oil. International Journal of Food Sciences and Nutrition 60(s2):114-123.

Mayne, S.T. 1996. Beta-karoten, carotenoids, and disease prevention in humans. FASEB J. 10:690-701.

Momuat, L.I. 2005. Karotenoid dan Pencegahan Aterosklerosis. Jurnal Ilmiah Sains 5(2):121-125.

Momuat, L.I. 2010. Aktivitas antioksidan dalam minyak kelapa yang dibuat dengan memanfaatkan aktivitas proteolitik wortel [Abstrak]. Di dalam: Seminar Molecular Biotechnology in Medicine and Bioindustry; The Third Gruber-Soedigdo Lecture 2010; Bandung, 27 Juli 2010. Institut Teknologi Bandung \& University of Groningen. Hlm 72 .
Nevin, K.G., T. Rajamohan. 2006. Virgin coconut oil supplemented diet increases the antioxidant status in rats. Food Chemistry 99(2):260-266.

Sesso, H.D., J.E. Buring, E.P. Norpus, J.M. Gaziano. 2004. Plasma Lycopene, Other Carotenoids and Retinol And The Risk Cardiovascular Disease in Women. Am. J. clin. Nutr. 79:47-53.

Sudjaswadi dan Sitanggang. 2005. Tanaman Obat Untuk Penyakit Jantung, Darah Tinggi, dan Kolesterol. Agromedia Pustaka, Jakarta.

Sugiman. 2000. Pengaruh Sari Jahe (Zingiber officinale roscoe) dalam Menghambat Oksidasi LDL Plasma Darah pada Mahasiswa. [Skripsi]. IPB, Bogor. 